\title{
Internet Banking Challenges among Customers in Selangor, Malaysia
}

\author{
Mahiswaran Selvanathan, PhD (Corresponding author) \\ SEGi University, Malaysia \\ Email: mahiswaran@gmail.com
}

Rubana Vighnesvaran

SEGi University, Malaysia

Voon Ying Teng

SEGi University, Malaysia

Faria Rabbi

SEGi University, Malaysia

Received: July 11, 2016 Accepted: September 01, 2016 Published: October 03, 2016

doi:10.5296/ijhrs.v6i3.9727 URL: http://dx.doi.org/10.5296/ijhrs.v6i3.9727

\begin{abstract}
Internet banking has been established a long time ago. All financial institutions particularly in Malaysia have developed secured online banking portals in line with the current trend of the industry. However, customer's acceptance towards internet banking is still a widely debatable issue. This study aims to investigate if factors such as security, price, perceived ease of use and customer resistance to change influences customers adoption of internet banking services. Questionnaire survey approach for data collection was adopted in this study. The responses of 120 respondents who visitedbank branches in Kota Damansara area were collected using convenience sampling method. The results of this study showed that hypotheses pertaining to security, price and perceived ease of use were supported but customer resistance to change was not supported. As compared to other factors, perceived ease of use is the strongest factor
\end{abstract}


that influences the adoption of internet banking services, followed by price, customer resistance to change and security. The result also revealed that young adults are more likely to adopt internet banking. There are several limitations in this study that needs to be considered. First, the scope of this study was limited to the banking outlets in a particular area, which were Kota Damansara, Selangor and not Malaysia as a whole. Second, the outcome that was obtained from the questionnaires may not be accurate because some respondents did not answer the questionnaire seriously. Furthermore, this study only involved a small number of respondents due to time constrain and the study only included the adopters of internet banking services and excluded the non-adopters. Last but not least, the factors chosen for this research may not cover all possible factors that influences customer's adoption of internet banking services. The findings presented in this research can be of assistance to customers especially those non-adopters of internet banking by providing them a deeper understanding of internet banking services and it would also help banks to identify the customer's perception and the level of customer's satisfaction towards internet banking services.

Keywords: Internet banking, Security, Price, Perceived ease of use and customer resistance to change.

\section{Introduction}

Internet banking can be defined as a system that allows the customers to perform traditional banking services such as balance enquiry, money transfer between accounts and settling utility bills online without visiting the banks (Munusamy, Chelliah, \&Annamalah, 2012). According to Munusamy et.al.(2012), Bank Negara Malaysia authorized all locally owned commercial banks to embark on internet banking and Malayan Banking Berhad (Maybank) was the first bank to initiate their online banking services to the public. In 2010, Yee and Faziharudean stated that only those banking institutions registered under the Banking and Financial Institution Act 1989 (BAFIA) and the Islamic Banking Act 1983 can offer internet banking to the customers. Since May bank Berhad lead this league to offer internet banking services, many other banks joined this global trend to gain competitive advantage over their competitors and fight for market share.

The number of internet banking adopters has increased drastically in recent years in Malaysia. According to the official portal of Bank Negara (2015), only $9.8 \%$ or 2.6 million people in Malaysia were willing to use internet banking services in 2005. However, by Jun 2015 there were 18.8 million internet banking subscribers in Malaysia, which comprises $61.9 \%$ of the total population in Malaysia. This shows that internet banking has become popular among Malaysian retail banking customers. At the same time, even though more than half of the total population in Malaysia are willing to adopt internet banking, financial institutions should not feel contented. In contrast, banks should look into customer loyalty and enlarging their customer base to earn higher profitability in the long run.

These days, the advantages of internet banking have become more apparent to retail banking customers. The advantages include availability, ease of use, safe time, relative advantage 
and so on (Ong et al., 2014). However, although the adoption of the internet banking services benefits the customers, many people are still reluctant to use it. The biggest obstacle of internet banking is the security issue (Polasik \& Wisniewski, 2009). The adoption of this service will be low if customers feel that internet banking is not save and secured to use (Aliyu, Younus, \&Tasmin, 2012). In addition, majority of the customers fear that their personal details will be leaked out to third parties for illegal purposes. Hence, trust must exist between the internet banking providers and the customers so that they can use internet banking without worrying about leakage of personal information because they have faith in the internet banking providers (Ong et al., 2014). In other words, the inability of the banks to protect the confidentiality of the customer's information and data may result in customers not trusting the security and safety of internet banking. Furthermore, the increasing number of internet deception in Malaysia has adversely affected the confidence of the customers towards internet banking. According to the National Cyber Security Agency under the Ministry of Science, Technology and Innovation, for the first half of 2014, atotal of 4,117 security incidents occurred and were investigated by them. Statistic cited from the agency's portal in 2015 shows that out of the total percentage of the security incidents occurred, internet fraud contributed the highest percentage $(51 \%)$ of the reported incidents for half year of 2014 and Cyber Security Malaysia predicted that these incidents have the potential to continue to become worst. Thus, high rate of internet fraud in Malaysia would negatively affect the attitude of the customers towards adoption of internet banking.

\section{Research Objectives}

The objectives of this research are as follows:

1. To determine the relationship between security and the adoption of internet banking.

2. To determine the relationship between price and the adoption of internet banking.

3. To determine the relationship between perceived ease of use and the adoption of internet banking.

4. To determine the relationship between customer resistance to change and the adoption of internet banking.

\section{Literature Review}

\subsection{Internet Banking}

Besides Munusamy et al. (2009),Hosein (2009) also defined internet banking as "an internet portal through which customers are able to use different kinds of banking services ranging from bill payments to making investments. However, the acceptance of customers towards internet banking plays a crucial role in determining the success or failure of this service. Sathye (1999) defined adoption as "the acceptance and continued use of a product, service and idea". There are many prior studies conducted pertaining to adoption of internet banking in different regions. In Pakistan, a study done by Kazi (2013) focused on adoption of internet banking among students of Khadim Ali Shah Bukhari Institute of Technology (KASBIT), Karachi, Pakistan. . Another study was carried out by Al-Ghaith, Sanzogni, and Sandhu (2010) 
to determine the factors that influence the adoption of electronic banking in Saudi Arabia. The questionnaire was distributed randomly in certain places of Saudi Arabia, but mostly in Riyadh, the capital city of Saudi Arabia (Al-Ghaith et al., 2010). On the other hand, a study conducted by Al-Smadi (2012), focused in Greater Aman Area, the capital of Jordan investigated the factors that affect the adoption of internet banking among banks' customers in Jordan. Unlike the research carried out by Kazi (2013) which focused on the students of higher education, other researchers including Al-Ghaith et al. (2010) and Al-Smadi (2012) carried out their research at one particular area and considered banks' customers at that particular area as a whole.

\subsection{Customer Resistance to Change}

Zander (1950) defined resistance to change as behaviour which is intended to protect an individual from the effects of real or imagined change. According to the Zaltman and Duncan (1977), resistance is any conduct that serves to maintain the status quo in the face of pressure to alter the status quo. When the banks come out with innovative services such as internet banking, the customers are often resistant to accept this new idea because it means that they need to learn something new or even do something differently. Almost all new products and services introduced will encounter the problem of getting accepted by the customers (Aliyu et al., 2012). Thus, the resistance towards new technology is inevitable because most customers are reluctant to change their behaviour. In Mauritius, a study conducted by Ayrga (2011), concluded that customer reluctant to change was a major hindrance that influenced the use of internet banking among the Mauritians. This study was focused on the two largest banks in Mauritius which are the State Bank of Mauritius and the Mauritius Commercial Bank. The research revealed that there was a negative relationship between customer's reluctance to change and adoption of internet banking. It was concluded that most of the Mauritians prefer the current traditional banking system and have lack of trust towards the security of electronic banking. In Australia, Sathye (1999) found out that $73 \%$ of personal respondents were aware of internet banking but they were not using this service compared to the business respondents. These findings showed that there was a resistance to change among the personal respondents towards this new service. She further mentioned that this might be due to the customer inertia. This assumption was supported by Daniel (1999) who stated that there is a high level of customer inertia in changing their established banking arrangements. As mentioned by Aliyuet al. (2012), the introduction of new technology is often resisted by a handful of customers because they are used with the present ways of operating and do not want any changes.

\subsection{Security}

According to Wang, Wang, Lin, and Tang (2003), security can be defined as the protection of information from unsanctioned intrusions or outflows. Other scholars, Casaló, Flavián, and Guinalíu (2008) defined security as the loss of personal data or money and errors in transactions. Majority of the banks customers are concerned about security of personal data and monetary transactions in the adoption of internet banking. When the banks customers feel internet banking is not safe and secure to use, they will not consider using this new service 
(Aliyu et al., 2012). Thus, the trust of banking customers towards the financial service providers play a crucial role in influencing the customer's acceptance and adoption of internet banking (Ong et al., 2014). The security issue of the online transactions over the internet is a primary concern of bank customers before using internet banking. The bulk of evidences from previous studies indicate that banks should take this factor seriously so that the non-adopters of internet banking are willing to use internet banking. In Poland, a study conducted by Polasik and Wisniewski (2009), revealed that security was a strong factor that influences Polish internet users. In the United Kingdom, Howcroft, Hamilton, and Hewer (2002) concluded that almost $50 \%$ of the respondents were citing security as an "extremely important" factor that discourages customers from using internet banking. Similarly, in a study conducted by Al-Sabbagh and Molla (2004) in Oman revealed that trust and perceived security were top two ranking determinants that influence the intention to adopt the internet banking services among the bank customers. The bank customers are unwilling to adopt internet banking services because they perceive that they will be exposed to security risks and dishonesty (Manoranjan, Bhusan, Kanta, \& Suryakanta, 2012).

\subsection{Price}

Zeithaml (1988) views price as something that is given up or sacrificed to obtain a product from a consumer's perspective. According to Chen, Gupta, and Rom (1994), perceived price consists of monetary price and non-monetary price. Price is an important factor that influences the adoption of internet banking. As discussed by Poon (2008), in order to gain competitive advantage of e-banking, financial institutions need to offer high quality services to satisfy customer's needs but at a lower cost. According to Aliyu et al. (2012), the price of technologies must be reasonable compared to other alternatives in the market so that the customers are willing to adopt new technologies. The study by Aliyu et al. (2012) also indicates that when customers feel the additional costs incurred for the internet banking is high, they would refuse to use this service even though it is convenient. In general, Sathye (1999) identified that there are two types of costs associated with internet banking. The first type of cost is cost related to internet activities and the second type of cost is the bank charges and administrative costs. According to Bradley and Stewart (2003)who conducted a study in Delphi, a town in Greece, concluded that there was a negative relationship between perceived cost and adoption of internet banking. . Other scholars, Colgate and Hedge (2001) revealed that price was the most important factor that influences the adoption of internet banking among New Zealand and Australian bank customers. In Malaysia, a study conducted by Tasmin et al. (2013), proves that cost was a major determinant to attract more customers to patronize this service.

\subsection{Perceived Ease of Use}

According to Davis (1989), perceived ease of use is defined as the extent to which an individual thinks that it would be effortless to use a particular system. Other scholars, Black, Lockett, Ennew, Winklhofer, and McKechnie (2002) view perceived ease of use as the user's perception of the level of easiness to use the system. Nowadays, most people particularly those who live in the towns cannot escape from the fast-paced life. Living in the fast pace of 
modern life requires us to do everything as quickly and efficiently as we can. If we fail to keep up with such lifestyle, we will fall back quickly compared to others. Thus, in the context of internet banking, customers will place convenience as their top priority before they choose to adopt internet banking (Ong et al., 2014). Aliyu et al. (2012) suggested that banks should provide online help and develop the online banking website in different languages to make it easier for consumers. According to Eastin (2002), convenience was the strongest contributing factor in exploring the usage of internet banking. In Malaysia, another study conducted by Ong et al. (2014) concluded that convenience was the strongest independent variable among customers who live in big cities. People who live in the urban areas were too busy and they do not have enough time to spend in bank branches to conduct their financial transactions. This study revealed that as long as the usage of the internet banking can makes their lives e easier; they are willing to adopt this technological change. In Bangladesh, a study conducted by Shah Alam, Khatibi, Solucis Santhapparaj, and Talha (2007), established that internet banking adopters considered internet banking as convenient, easy to use and more suitable for those who are technology illiterate particularly the senior citizens.

\section{Analysis and Results}

\subsection{Correlation Analysis}

Table 1displays the correlation analysis results of this study which is used to determine the relationship between the dependent variable and independent variables. Based on the survey results, adoption of internet banking showed a moderate correlation with customer resistance to change (.584) and price (.596) whereas, the adoption of internet banking showed a high correlation with the perceived ease of ease (.699) and indicated a low correlation with security (.335).Customer resistance to change showed a moderate correlation with the adoption of internet banking (.584) and price (.554). On the other hand, customer resistance to change showed a high correlation with perceived ease of use (.714) and showed a low correlation with security (.376). Another independent variable, perceived ease of use showed a high correlation (.699) with the adoption of internet banking, customer resistance to change (.714) and price (.701) but showed a moderate correlation with security (.587). On the other hand, price showed a moderate correlation with the adoption of internet banking (.596), customer resistance to change (.554) and security (.566) but a high correlation with perceived ease of use (.701).Lastly, security showed a low correlation with the adoption of internet banking (.335) and customer resistance to change (.376). Nevertheless, security showed a moderate correlation with perceived ease of use (.587) and price (.566). 
Table 1: The results of correlation analysis for each variable

\begin{tabular}{|l|l|l|l|l|l|}
\hline & & & & \\
\\
\end{tabular}




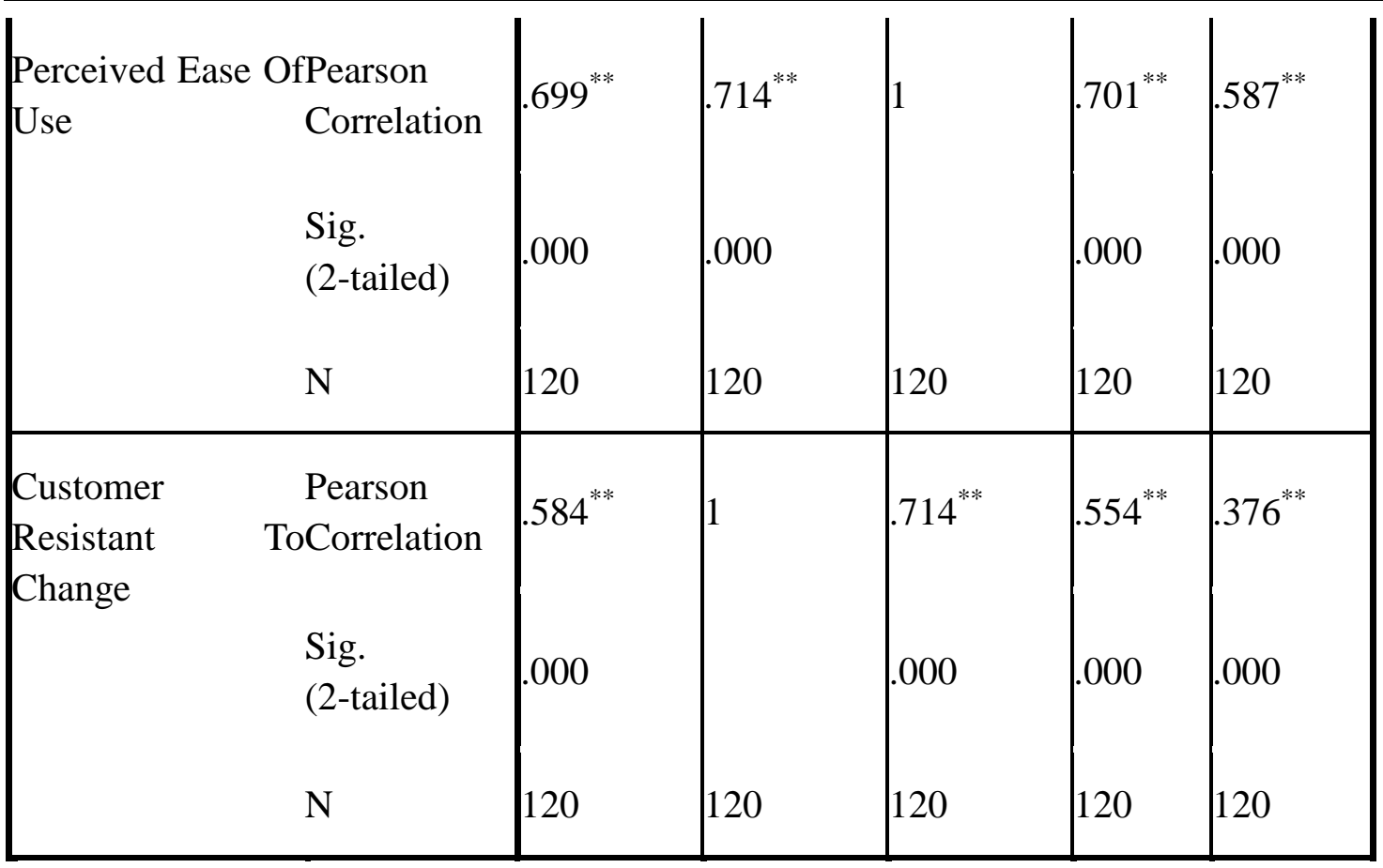

**. Correlation is significant at the 0.01 level (2-tailed).

\subsection{Multiple Regression Analysis}

Multiple regression analysis was conducted to test the hypotheses in this study. The $\mathrm{R}^{2}$ value for independent variables which includes customer resistance to change, perceived ease of use, price and security in Table 2 shows 0.538 for the dependent variable, adoption of internet banking in this study. This indicates that approximately $53 \%$ of the dependent variable (adoption of internet banking) will explained by the four independent variables, customer resistance to change, perceived ease of use, price and security. The arrangement of the strength among the independent variables (customer resistance to change, perceived ease of use, price and security) that contributes to the adoption of internet banking (dependent variable) are perceived ease of use $(B=.529)$, followed by price $(B=.246)$, customer resistance to change $(B=.131)$ and lastly security $(B=-.165)$. The significant value for each variable is used to determine whether all of these variables contributed significantly towards the regression equation. Thus, thus the hypotheses were accepted if the significant value was less than 0.05 . Table 3 shows the result of hypotheses testing of regression analysis. 


\begin{tabular}{|l|l|l|l|l|}
\hline $\begin{array}{l}\text { Dependent } \\
\text { variable }\end{array}$ & Independent variables & Beta & Sig. & $\begin{array}{l}\text { R } \\
\text { Square }\end{array}$ \\
\hline $\begin{array}{l}\text { The adoption of } \\
\text { internet banking }\end{array}$ & Security & -.165 & .047 & .538 \\
\cline { 2 - 4 } & Price & .246 & .009 & \\
\cline { 2 - 4 } & Perceived Ease of Use & .529 & .000 & \\
\cline { 2 - 4 } & Customer resistance to change & .131 & .154 & \\
\hline
\end{tabular}

Table 2: The results of Regression Analysis

Table 3: The hypotheses results

\begin{tabular}{|l|l|}
\hline Hypotheses & Results \\
\hline $\begin{array}{l}\text { H1. There is a positive relationship between security and adoption of internet } \\
\text { banking. }\end{array}$ & Accepted \\
\hline $\begin{array}{l}\text { H2. There is a positive relationship between price and adoption of internet } \\
\text { banking. }\end{array}$ & Accepted \\
\hline $\begin{array}{l}\text { H3. There is a positive relationship between perceived ease of use and adoption } \\
\text { of internet banking. }\end{array}$ & Accepted \\
\hline $\begin{array}{l}\text { H4. There is a positive relationship between customer resistance to change and } \\
\text { adoption of internet banking. }\end{array}$ & Rejected \\
\hline
\end{tabular}

Based on findings in Table 3 above, the hypotheses of independent variables, security, price and perceived ease of use were accepted in this study. However, the hypothesis of customer resistance to change was rejected in this study.

\section{Conclusion}

The primary objective of this study was to determine if price, security, perceived ease of use 
and customer resistance to change influences adoption of online banking. Based on the findings of this study, all factors have a positive relationship towards adoption of internet banking except for customer resistance to change. The results of this study have practical implications on both banks with or without internet banking services and customers. Based on the gathered information in this study, several recommendations were made which may be useful to the banking sector. Perceived ease of use is customer's primary concern to adopt internet banking, therefore it was suggested that internet banking providers design online portals to be more user-friendly and suitable to all age group of customers. In terms of price, it is suggested that the internet banking providers should not charge unreasonable price or any hidden costs to the customers. Although, security has low correlation to adoption of internet banking, the providers should at all times maintain high level of security and ensure confidentiality of customer's data in order to maintain the trust and loyalty of customers.

\section{References}

Al-Ghaith, W., Sanzogni, L., \& Sandhu, K. (2010). Factors influencing the adoption and usage of online services in Saudi Arabia. EJISDC: The Electronic Journal on Information Systems in Developing Countries, (40), 1.

Aliyu, A. A., Younus, S. M., \&Tasmin, R. (2012). An Exploratory Study on Adoption of Electronic Banking: Underlying Consumer Behaviour and Critical Success Factors: Case of Nigeria. Business and management Review, 2(1), 1-6.

Al-Sabbagh, I., \&Molla, A. (2004). Adoption and use of internet banking in the Sultanate of Oman: An exploratory study. Journal of Internet Banking and Commerce, 9(2), 1-12.

Al-Smadi, M. O. (2012). Factors affecting adoption of electronic banking: An analysis of the perspectives of banks' customers. International Journal of Business and Social Science, 3(17).

Ayrga, A. (2011). Is Mauritius ready to e-Bank? From a customer and banking perspective. Journal of Internet Banking and Commerce, 16(1), 1.

Jo Black, N., Lockett, A., Ennew, C., Winklhofer, H., \&McKechnie, S. (2002). Modelling consumer choice of distribution channels: an illustration from financial services. International Journal of Bank Marketing, 20(4), 161-173.

Bradley, L., \& Stewart, K. (2003). The diffusion of online banking. Journal of Marketing Management, 19(9-10), 1087-1109.

Casaló, L. V., Flavián, C., \&Guinalíu, M. (2008). The role of satisfaction and website usability in developing customer loyalty and positive word-of-mouth in the e-banking services. International Journal of Bank Marketing, 26(6), 399-417.

Chen, I. J., Gupta, A., \& Rom, W. (1994). A study of price and quality in service operations. International Journal of Service Industry Management,5(2), 23-33. 


\section{Al Macrothink}

International Journal of Human Resource Studies

ISSN 2162-3058 2016, Vol. 6, No. 3

Colgate, M., \& Hedge, R. (2001). An investigation into the switching process in retail banking services. International Journal of Bank Marketing, 19(5), 201-212.

Davis, F. D. (1989). Perceived usefulness, perceived ease of use, and user acceptance of information technology. MIS quarterly, 319-340.

Eastin, M. S. (2002). Diffusion of e-commerce: an analysis of the adoption of four e-commerce activities. Telematics and informatics, 19(3), 251-267.

Hosein, N. Z. (2009). Internet banking: An empirical study of adoption rates among midwest community banks. Journal of Business \& Economics Research, 7(11), 51.

Howcroft, B., Hamilton, R., \&Hewer, P. (2002). Consumer attitude and the usage and adoption of home-based banking in the United Kingdom.International journal of bank marketing, 20(3), 111-121.

Kazi, A. K. (2015). An empirical study of factors influencing adoption of Internet banking among students of higher education: Evidence from Pakistan. The Journal of Internet Banking and Commerce, 2013.

Manoranjan, D., Bhusan, M. B., Kanta, B. S., \&Suryakanta, M. (2012). Understanding Consumers Risks Perception for Banking on the Internet.International Journal of Engineering and Management Sciences, IJEMS,3(2), 146-150.

Munusamy, J., Annamalah, S., \&Chelliah, S. (2012). A Study of Users and Non-Users of Internet Banking in Malaysia. International Journal of Innovation, Management and Technology, 3(4).

Munusamy, J., De Run, E. C., Chelliah, S., \&Annamalah, S. (2012). Adoption of retail internet banking: A study of demographic factors. Journal of Internet Banking and Commerce, 17(3).

Ong, T. S., Hong, Y. H., Teh, B. H., Soh, P. C. H., \& Tan, C. P. (2014). Factors that affect the adoption of internet banking in Malaysia. International Business Management, 8(2), 55-63.

Polasik, M., \& Piotr Wisniewski, T. (2009). Empirical analysis of internet banking adoption in Poland. International Journal of Bank Marketing, 27(1), 32-52.

Poon, W. C. (2007). Users' adoption of e-banking services: the Malaysian perspective. Journal of Business \& Industrial Marketing, 23(1), 59-69.

Shah Alam, S., Khatibi, A., SolucisSanthapparaj, A., \&Talha, M. (2007). Development and prospects of internet banking in Bangladesh.Competitiveness Review: An International Business Journal, 17(1/2), 56-66.

Sathye, M. (1999). Adoption of Internet banking by Australian consumers: an empirical investigation. International Journal of bank marketing, 17(7), 324-334.

Tasmin, R., Aliyu, A. A., Norazlin, H., \&Takala, J. (2013). The Impact of Online Banking on Customer Service Delivery in the Malaysian Banking Industry: Kano's Model Appraoch. 


\section{Macrothink}

International Journal of Human Resource Studies

ISSN 2162-3058 2016, Vol. 6, No. 3

In Diversity, Technology, and Innovation for Operational Competitiveness: Proceedings of the 2013 International Conference on Technology Innovation and Industrial Management (pp. S4_175-188). ToKnowPress.

Wang, Y. S., Wang, Y. M., Lin, H. H., \& Tang, T. I. (2003). Determinants of user acceptance of Internet banking: an empirical study. International journal of service industry management, 14(5), 501-519.

Yee, B. Y., \&Faziharudean, T. M. (2010). Factors affecting customer loyalty of using internet banking in Malaysia. Journal of Electronic Banking Systems, 2010(2010), 21.

Zaltman, G., \& Duncan, R. (1977). Strategies for planned change. Wiley.

Zander, A. (1950). Resistance to change - its analysis and prevention.Advanced Management Journal.

Zeithaml, V. A. (1988). Consumer perceptions of price, quality, and value: a means-end model and synthesis of evidence. The Journal of marketing, 2-22.

\section{Copyright Disclaimer}

Copyright for this article is retained by the author(s), with first publication rights granted to the journal.

This is an open-access article distributed under the terms and conditions of the Creative Commons Attribution license (http://creativecommons.org/licenses/by/3.0/). 